mary of Results, Supplement to Zoological Report, and Map. London: Dulua and Company.

Thomas, I. 1993 Late Pleistocene environments and Aboriginal settlement patterns in Tasmania. Australian Archaeology 36:1-11.

Whitehead, P.J., Bowman, D.M.J.S. and Tidemann, S.C. 1992 Biogeographic patterns, environmental correlates and con- servation of avifauna in the Northem Territory, Australia. Journal of Biogeography 19:151-61.

Wilson, B.A., Brocklehurst, P.S., Clark, M.J. and Dickinson, K.J.M. 1991 Vegetation survey of the Northem Territory. Conservation Commission of the Northem Territory Technical Report No. 49.

\title{
The Gooreng Gooreng Cultural Heritage Project: Some proposed directions and preliminary results of the archaeological program
}

\section{lan Lilley and Sean UIm}

This paper outlines the working hypotheses guiding exploratory archaeological investigations on the coast between Bundaberg and Gladstone in south-central Queensland (Fig. 1), and reports some early results and their possible wide-ranging, interdisciplinary Aboriginal cultural heritage study which flows from earlier investigations by Williams (1981). Preliminary linguistic research has already been published (Jolly 1994), while an ethno- and oral-historical

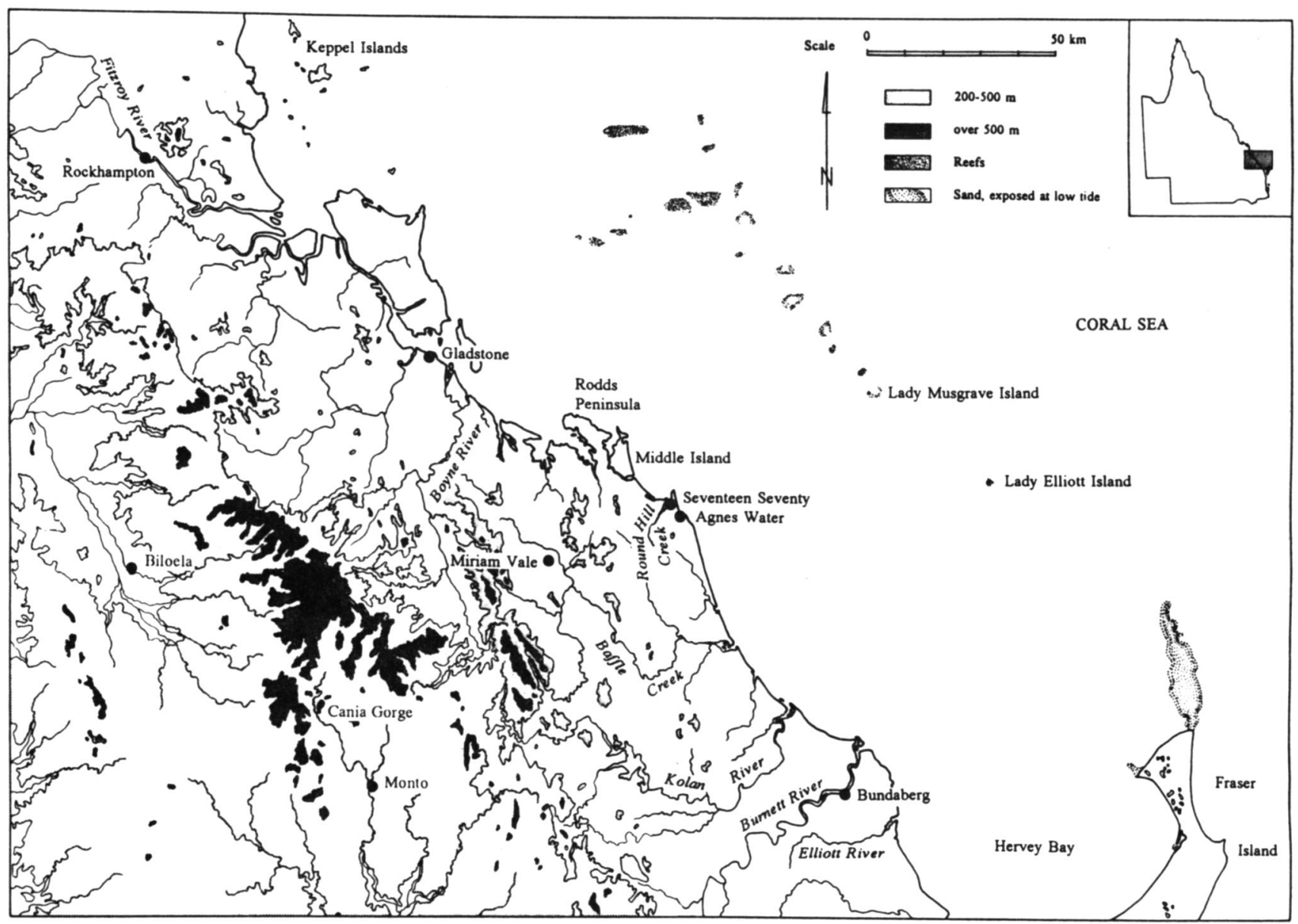

Figure 1 The study area, showing places mentioned in the text.

implications. The research was undertaken in collaboration with the Gurang Land Council and forms part of a

Aboriginal and Torres Strait Islander Studies Unit, The University of Queensland, Brisbane, Qld 4072, Australia. study has recently commenced. The archaeological surveys reported here are part of a multi-stage project focussing on the abovementioned coastal region and on the sandstone caves and rockshelters of Cania Gorge near Monto, $150 \mathrm{~km}$ to the west. The surveys were designed to test 
several propositions about the archaeological record in the coastal zone and establish a solid basis for continuing archaeological research and cultural heritage management in the area.

Of greatest interest at this early stage of the project are questions concerning the antiquity of human occupation in the coastal region and whether a concentration of sites in estuaries and near absence of material on ocean beaches reflects past Aboriginal behaviour, recent geological processes or patterns of archaeological research. The last is a distinct possibility, for archaeological knowledge of the study area is generally poor. Prior to the present investigation, the sole systematic survey undertaken in the study area (Burke 1993) discovered some 90 sites on the coast between Gladstone and Seventeen Seventy (Fig. 1), but only 20 sites are listed in State Government records for the $120 \mathrm{~km}$ of coast from Seventeen Seventy to the Elliott River south of Bundaberg (Fig. 1).

As will be made clear later in the paper, the influence of coastal geomorphological processes on site distribution patterns may also have been profound. For this reason later stages of the project will relate our findings to those from northern New South Wales (e.g. Sullivan 1982; see also Thom 1984), where the coastal geomorphology is similar to that of the study area, as well as those from the rest of southeast Queensland, where it is not. The work of scholars such as Head (1983) and Godfrey (1989) on the Victorian coast and Bird $(1992,1995)$ in north Queensland will also be taken into account.

Resolution of questions concerning sampling effectiveness and post-depositional processes will allow changes in past human behaviour in the study area to be compared with those immediately to the north, where the Keppel Islands and adjacent coast (Fig. 1) have been examined by Rowland (e.g. 1982a, 1982b), and to the south, where McNiven (1993) and others (e.g. Frankland 1990; Lauer 1977) have investigated the Fraser Island-Great Sandy region. As will be made clear below, the exploration of links with areas to the south will be particularly important as the study develops, as it will promote understanding of patterns of regional interaction and thus help integrate the archaeology of the study area with that of the wider southeast Queensland region.

\section{The study area}

The study area occupies an unusual biogeographic and geomorphic position, which for two reasons may have important ramifications for the interpretation of its archaeological record. First, it lies on the northern edge of southeast Queensland, which forms a broad ecotone between the coastal environments of the tropical north and the temperate south (Keast 1981; Stanton and Morgan 1977).

Second, the study area includes the only significant length of the heavy mineral coast (Gill 1982) in southeast Queensland which is open to full oceanic conditions. This coast is typified by broad, 'Z'-curved, quartz-sand embayments between often widely-spaced rocky headlands (Roy and Thom 1981). Most of the coast south to the New South Wales border is protected by the massive transgressive dunes of Fraser, Moreton, and North and South Strad- broke Islands, while to the north the coast is shielded by the Great Barrier Reef.

In the area of investigation, the distinctive high dures of the sand islands to the south are replaced by prograded shorelines composed of low beach-ridge systems which have formed since sea level stabilisation. This change results from the northwesterly shift in coastal orientation north of Fraser Island, as can be determined from the characteristics of the Cooloola coast. The only other significant stretch of mainland coast in southeast Queensland which is open to the ocean, Cooloola has high dunes oriented northnortheast like the sand islands to its north and south.

Linguistic and ethnographic evidence (see Jolly 1994; Williams 1981) indicates that while Aboriginal people in the study area undoubtedly had links to the north, most of their cultural ties at contact were to the south. Gooreng Gooreng, for instance, is closely related to Kabi Kabi and Waka Waka rather than to languages in the Rockhampton area. While detailed working hypotheses concerning such questions have yet to be formulated, it seems likely the biogeographic and geomorphic features of the study area, and specifically its ecotonal characteristics, will influence archaeologically-detectable features of past human behaviour, which may reflect cultural patterns more common in tropical regions to the north. Alternatively, it may prove to be the case that the archaeological record will look more like that from Fraser Island, for example, where culturallyrelated people lived at contact, or northern New South Wales, which has more similar coastal geomorphology. It is also possible, as Rowland $(1987,1989)$ suggests, that the lack of coastal protection by islands or reefs may produce an archaeological record distinct in composition and distribution from those to the north and south owing to different patterns of site survival.

\section{The problem}

The surveys sought to test at a preliminary level the conclusions reached by Rowland (1987:17) after his 'broad cursory investigation' of the coast from Bundaberg to Round Hill Creek. He noted

1. 'substantial middens are rare'

2. sites are located 'either atop rocky headlands or in sheltered estuaries', and

3. 'smaller scatters of shells are located along open beaches'.

He went on to state (Rowland 1987:17)

Whether this is a true reflection of Aboriginal settlement patterns in the area or an expression of geomorphological factors is a problem still to be resolved. Certainly the extent of erosion along the open coastal dune systems of the area would suggest that loss of sites may be an important factor affecting the above pattern.

Burke's (1993) findings regarding the area from Round Hill Creek to Gladstone have also been considered. Though it extended south to overlap with Rowland's survey at Round Hill Creek, Burke's study was primarily concerned with the Curtis Coast to the north of Rodds Peninsula. The Curtis Coast is sometimes called the Tortured Coast owing to its convoluted margins and is quite unlike the coast south of 
Rodds Peninsula. While the project will in time consider this northern area, it has as yet investigated only the area between the peninsula and Bundaberg, concentrating on northern parts including Rodds Peninsula, Deepwater and Eurimbula National Parks near Agnes Water, and Middle Island, which was the subject of a first-stage cultural resource management study for the sand mining company RZM Pty Ltd (Lilley 1994).

\section{Field methods and results}

Field methods are only outlined in general terms as they will be described at length in detailed site reports to be produced at later stages of the study. Surveys other than those undertaken for heritage management studies have been extensive but generally of low intensity. Field crews systematically examined parts of the abovementioned areas, either on foot or, as conditions required, from a boat, fourwheel-drive vehicle or quad motorcycle. While field crews took advantage of every opportunity to examine soil profiles in road cuttings, creek banks and the like, no excavation, augering or other subsurface testing was undertaken.

Initially it seemed as if the surveys would simply confirm Rowland's findings. While sites, principally shell middens, were relatively common on estuaries, investigation of a number of beach areas found little or no surface archaeological material. Similarly, very little was found on the margins of swamps behind the beach-ridge systems, though few were examined. These results were matched by those reported by Burke (1993), who found that while sites were common on estuaries and the beaches of the sheltered stretches of the Curtis Coast northwest of Rodds Peninsula, they were rare on the open coast between Agnes Water and Bustard Head on Middle Island.

Results of fieldwork on Middle Island changed this picture substantially. Burke reported 12 sites on the island, seven clustered around Bustard Head and the other five spread down the eastern half of the island. By adopting a survey strategy which, unlike Burke's, took advantage of a comprehensive grid of drilling lines created by the sand miners, it was found the beach-ridge systems on the island were covered from north to south in shallow but very extensive complexes of middens. A preliminary examination of parts of Rodds Peninsula suggests similar patterns may be discovered there, but the matter is complicated by sand mining which took place in the late 1960s in the main area of beach ridges.

\section{Discussion}

As is often the case when following up investigations of the sort undertaken by both Rowland and Burke, it seems as if the site distribution they discerned - specifically, the concentration of sites in estuaries - results at least in part from their survey strategies. There is undoubtedly a lot of sites on the estuaries, and very few on the beaches, but there is also a lot in the beach-ridge systems if Middle Island is any indication. Such systems extend along the coast throughout the study area, which suggests there is an abundance of undiscovered archaeological material between Bundaberg and Gladstone.

What of the implications of this emerging site distribution pattern for the antiquity of human occupation in the region? At this stage it seems unlikely the discovery of shallow surface or near-surface sites on the beach-ridge systems will appreciably alter the time depth of occupation suggested by the presence of sites on estuaries. The estuaries can only have developed since sea level stabilisation roughly 6000 years ago. There are detailed unpublished data concerning the chronology of dune formation and beachridge progradation in the south of the study area, but as far as can be determined there are no such details for the northern part of the region. Summaries of these data in mining journals (e.g. Queensland Geological Survey 1981) mention Pleistocene dunes near Bundaberg, while survey crews have observed orange-red deposits exposed in a sand quarry at Seventeen Seventy, both of which suggest the presence of at least relicts of formations like the Inner Barrier (Roy and Thom 1981) on the New South Wales coast or perhaps an even older barrier system like that found at Cooloola (Tejan-Kella et al. 1990).

The same mining reports also mention PleistoceneHolocene beach ridges overlying Holocene mangrove muds, which presumably means the ridges are entirely Holocene, similar to the Outer Barriers in New South Wales (Roy and Thom 1981). Flood's (1981) findings at Deception Bay near Brisbane indicate that like those in New South Wales, these Holocene ridges are, more precisely, mid- to late Holocene in age, as they only began forming at the end of the last marine transgression. In short, while the conditions exist for earlier material to be discovered, the bulk of the archaeological record in the areas examined so far can only date to the last 5000-6000 years.

Excavations currently in progress at Eurimbula and Rodds Peninsula aim in part to determine whether the ridges and any sites within them, rather than on them, formed continuously or in episodes separated by substantial periods of beach erosion. Broadly similar landscapes may have markedly different geomorphological histories. In some cases, the geomorphology suggests there were major breaks in progradation. On Middle Island, for instance, there are two parallel sets of ridges separated by mud-flats and swamps, suggesting two phases of dune building. Similarly, the western coast of Rodds Peninsula exhibits both cheniers, or shelly beach-ridges, and ordinary sand beach-ridges, indicating 'erosive phases between major depositional events' (Sullivan and O'Connor 1993:777). In the Eurimbula-Round Hill Creek area, on the other hand, it appears from a lack of similar evidence as if the beach ridges have developed relatively continuously.

As Thom (1974) notes, dating the periodicity of beachridge formation is fraught with technical problems. Bearing that in mind, Flood (1981) defines three major breaks in ridge accretion at Deception Bay. The first is between 4500 and 3500 years BP, the second between 3000 and 1500 years BP, and the third between $1000 \mathrm{BP}$ and 550 years BP. In view of the evidence of the cheniers at Rodds Peninsula, it is interesting to note these periods overlap with those proposed for the drier, erosional phases linked with chenier development in tropical Australia, namely 3500. $2600 \mathrm{BP}, 2100-1600 \mathrm{BP}$ and the last 1000 years (Sullivan and O'Connor 1993:779).

It also remains to be seen through detailed geomorphological study planned for the future whether progradation 
in the study area continues, ceased recently or ceased in the more distant past. Thom's (1974) studies in New South Wales led him to argue progradation may have ceased as early as 3000-4000 years ago. Flood (1981), on the other hand, argues beach ridges were being formed at Deception Bay within the last 500 years or so. The geomorphology and contemporary marine mollusc fauna in the study area suggests progradation is occurring there now, a matter addressed again below. It is clear, though, that much remains to be done in sorting out mid- to late Holocene climatic and geomorphological change in the study area and elsewhere.

The foregoing matters relate to questions concerning past and present beach erosion, which in at least some parts of the study area has been significant in recent times. This gives some credence to the idea that the lack of beach sites is at least partly a product of geomorphological rather than cultural processes. Unfortunately there are no detailed studies of coastal erosion in the study area, but the matter will be pursued with the Beach Protection Authority and through the examination of diachronic air photo records.

Such questions also link with patterns in the species composition of middens. First, pipis (Donax deltoides) occur in some middens but do not appear to inhabit adjacent intertidal environments now. If demonstrated conclusively, this situation may indicate local or more widespread environmental change affecting ocean beaches, the implications of which for site survival patterns and past human behaviour remain to be fully explored. Second, many estuarine and beach-ridge sites are dominated by the cockle Anadara trapezia. These bivalves do not live in the area today (Shanco and Timmins 1975). The contemporary marine mollusc fauna is dominated by Potamid gastropods such as Cerithidae, Pyrazus, Telescopium and Terebralia, all of which prefer a muddy mangrove environment, and Saccostrea oysters, which grow on mangroves and rocks. As Sullivan and O'Connor's (1993:785) research indicates, the foregoing implies all the anthropogenic Anadara deposits may have been laid down when the cheniers were being built up, because shellfish which prefer muddy mangrove conditions and species such as oyster would occur in middens deposited during phases of mangrove-flat progradation and sandy beach-ridge building. Strangely, in view of the current abundance of gastropods and oysters, the surveys located remarkably few gastropod shells in the middens recorded to date, though oysters occur in a reasonable proportion of sites, particularly on the southern ends of Middle Island and Rodds Peninsula.

Why so few gastropods? It may be the surveys simply failed to locate such gastropod middens as occur in the area. Perhaps, though, the beach ridges were occupied mainly during erosive phases, when Anadara may have dominated the local marine mollusc fauna, rather than during the episodic depositional events which formed the ridges, when oysters and mud-dwelling gastropods would have been most abundant. This does not mean the ridges were not occupied from very early in the dune-building sequence. Nor does it mean the area in general was abandoned dur ing times of progradation. Unless there has been a dramatic change in local geomorphic conditions since AD 1770 (which cannot be ruled out), James Cook's (Beaglehole 1955:324) observations of smoke and discovery of a hastilyabandoned camp at the mouth of Round Hill Creek demonstrates Aboriginal people did live in the area while progradation was occurring (and, it should be noted, before European colonisation elsewhere could have pushed people into a place they would not normally have used).

\section{Conclusion}

Recent archaeological research and cultural heritage management surveys in the Bundaberg-Gladstone area have expanded our knowledge of coastal site distribution patterns in the region by discovering a hitherto unsuspected abundance of archaeological material on mid- to late Holocene beach ridges inland from the present shoreline. It had previously been thought that coastal sites in the region were clustered on the tidal estuaries of major waterways. Chronological parameters have also been sketched out, and limit most coastal occupation in the areas examined to the last 5000-6000 years. Finally, questions have been raised concerning the nature and extent of recent environmental change, and particularly geomorphological variation and related shifts in marine mollusc fauna. A multistaged program of more detailed archaeological and geomorphological investigations which began in the area in 1995 and which will be reported on in due course is building upon these findings to help provide a firm basis for studies of Aboriginal culture and history in the region.

\section{Acknowledgements}

We thank Michael Williams for his unflagging personal encouragement of this research and, in his capacity as Director of the Aboriginal and Torres Strait Islander Studies Unit at the University of Queensland, for providing funding for the work in 1993-1994. The Gurang Land Council has been an active participant in all stages of the work and we thank them for their continuing assistance and firm support. Luke Godwin (Queensland Department of Environment and Heritage) has provided very considerable assistance and advice, while Stan Wollen (RZM Pty Ltd) provided the opportunity to look at Middle Island in detail and graciously agreed to the publication of an outline of our findings. For field assistance we are grateful to Colin Johnson, Michael Williams, Mervyn Johnson, Cedric Williams, Hilton Johnson, Ron Johnson Sr, Ron Johnson Jr, Vicki Johnson, Deborah Brian, John Richter, Shane Coghill, Joe Kilroy, Debbie Kilroy, Garrick Hitchcock, Chris Clarkson, Catriona Murray, Lynette Hughes and Sarah Sheridan. John Richter also prepared the map. Jay Hall, Deborah Brian and an anonymous referee looked over drafts of the paper but any errors of fact or interpretation rest with us.

\section{References}

Beaglehole, J.C. (ed.) 1955 The Journals of Captain James Cook and his Voyage of Discovery: The Voyage of the Endeavour 1768-1771. Cambridge: Cambridge University Press.

$\rightarrow$ Bird, M.K. 1992 The impact of tropical cyclones on the archaeological record: An Australian example. Archaeology in Oceania 27(2):75-86. 
Bird, M.K. 1995 Coastal morphodynamics and the archaeological record: Further evidence from Upstart Bay, north Queensland. Australian Archaeology 40:57-8.

Burke, C. 1993 A Survey of Aboriginal Archaeological Sites on the Curtis Coast, Central Queensland. Report to the Queensland Department of Environment and Heritage.

Flood, P.G. 1981 Carbon-14 dates from the coastal plains of Deception Bay, southeastern Queensland. Queensland Government Mining Journal 82:19-23.

Frankland, K. 1990 Booral: A preliminary investigation of an archaeological site in the Great Sandy Strait region, southeast Queensland. Unpublished B.A.(Hons) thesis, Department of Anthropology and Sociology, The University of Queensland.

Gill, E.D. 1982 Eight Coasts of Australia. Mt Waverley, Victoria: Division of Applied Geomechanics, CSIRO. Technical Report No. 119.

$\rightarrow$ Godfrey, M.C.S. 1989 Shell midden chronology in southwestem Victoria: Reflections of change in prehistoric population and subsistence. Archaeology in Oceania 24(2):65-9.

$\rightarrow$ Head, L. 1983 Environment as artefact: A geographic perspective on the Holocene occupation of southwestern Victoria. Archaeology in Oceania 18(2):73-80.

Jolly, L. 1994 Gureng Gureng. A language program feasibility study. Brisbane: The University of Queensland. Aboriginal and Torres Strait Islander Studies Unit Research Report Series No. 1.

Kèast, A. (ed.) 1981 Ecological Biogeography of Australia: Boston: W. Junk.

Lauer, P.K. 1977 Report of a Preliminary Ethnohistorical and Archaeological Survey of Fraser Island. St Lucia: Anthropology Museum, The University of Queensland. Occasional Papers in Anthropology 8:1-38.

Lilley, I.A. 1994 An Archaeological Assessment of Proposed Sand-Mining on Middle Island, Coastal Central Queensland. Report to the Queensland Department of Environment and Heritage for RZM Pty Ltd. University of Queensland Archaeological Services Unit Report No. 244.

McNiven, I.J. 1993 Corroboree Beach, Fraser Island: Archaeological Survey and Management Recommendations. Vol. 1. Report to the Queensland Department of Environment and Heritage.

Rowland, M. 1982a Keppel Island marine specialists: An adaptation to the southern Great Barrier Reef province. In
S. Bowdler (ed.) Coastal Archaeology in Eastern Australia: Proceedings of the 1980 Valla Conference on Australian Prehistory, pp.114-20. Canberra: Department of Prehistory, Research School of Pacific Studies, The Australian National University. Occasional Papers in Prehistory, No. 11.

Rowland, M. 1982b Stockyard Point - Capricom Coast: A brief note from terra incognita. Australian Archaeology 15:35-42.

Rowland, M. 1987 Preliminary archaeological survey of coastal areas of the Bundaberg 1:250,000 Sheet (KE). Unpublished internal report. Queensland Department of Environment and Heritage.

Rowland, M. 1989 Population increase, intensification or a result of preservation? Explaining site distribution patterns on the coast of Queensland. Australian Aboriginal Studies 1989/2:32-42.

Roy, P.S. and Thom, B.G. 1981 Late Quaternary marine deposition in New South Wales and southern Queensland an evolutionary model. Journal of the Geological Society of Australia 28(4):471-89.

Shanco, P. and Timmins, R. 1975 Reconnaissance of southem Bustard Bay tidal wetlands. Operculum 4(3-4):149-54.

Stanton, J.P. and Morgan, M.G. 1977 The Rapid Selection and Appraisal of Key and Endangered Sites: The Queensland Case Study. Report to the Department of Environment, Housing and Community Development. Armidale: School of Natural Resources, The University of New England.

Sullivan, M.E. 1982 Aboriginal shell middens in the coastal landscape of New South Wales. Unpublished Ph.D. thesis, Department of Prehistory and Anthropology. The Australian National University, Canberra.

Sullivan, M. and O'Connor, S. 1993 Middens and cheniers: Implications of Australian research. Antiquity 67:776-88.

Tejan-Kella, M.S., Chittleborough, D.J., Fitzpatrick, R.W., Thompson, C.H., Prescott, J.R. and Hutton, J.T. 1990 Thermoluminescence dating of coastal sand dunes at Cooloola and North Stradbroke Island, Australia. Australian Journal of Soil Research 28:465-81.

Thom, B.G. 1974 Coastal erosion in eastem Australia. Search 5(5):198-209.

Thom, B.G. (ed.) 1984 Coastal Geomorphology in Australia. Sydney: Academic Press.

Williams, M. 1981 Traditionally, my country and its people. Unpublished M.Phil.(Qual.) report, Griffith University, Brisbane.

\title{
Moulding and casting Aboriginal carved trees
}

\author{
Gordon Grimwade', Karen Mickan ${ }^{2}$ and Alison Darroch ${ }^{3}$
}

The documentation, conservation and interpretation of isolated cultural heritage sites present diverse challenges. In the wet tropics of northeast Australia (Fig. 1) these challenges are exacerbated by adverse climatic conditions.

1 Cultural Heritage Consultant, PO Box 9, Yungaburra, QLD 4872, Australia.

2 Preparator, Queensland Museum, Brisbane, QLD 4000, Australia.

3 Archaeologist, Caims, QLD 4870, Australia.
Organic materials suffer severely in such conditions. Aboriginal carved trees of the wet tropics are little known resources of the Wet Tropics of Queensland World Heritage Area extending north from Townsville to just south of Cooktown. Their documentation and research has been minimal.

Forestry officers and site recorders have provided brief descriptions of such trees over the past forty or so years. In 1988 a report was commissioned by the (then) Depart- 